Biol. Stud. 2013: 7(2); 185-194 • DOI: https://doi.org/10.30970/sbi.0702.273

www.http://publications.Inu.edu.ua/journals/index.php/biology

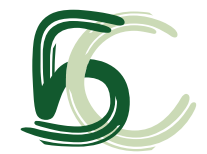

UDC: $616.33+612.018 .2+612.881$

\title{
AGE-DEPENDENT CHANGES IN GASTROINTESTINAL MOTILITY
}

\author{
O. lefimenko, I. Savchenko, T. Beregova
}

Taras Shevchenko National University of Kyiv, 64/13, Volodymyrska St., Kyiv 01601, Ukraine

The mechanisms of the motor function are studied for more than 100 years, however, they have not been established completely. Understanding those mechanisms is of great importance since the disturbances of gastrointestinal motility underlay in pathogeneses of many diseases, such as colitis, constipations, irritable bowel syndrome and others. This review is devoted to analysis of literature data of the age-related changes in the motility function of digestive tract. We have searched articles on a particular issue and have analyzed them in accordance with the parts of the digestive tract. Main attention has been paid to age-dependent functional and regulatory changes in the digestive tract. The mechanisms underlying in pathogenesis of age-related diseases of motor function of the digestive tract have not been deeply studied. Without the establishment of these mechanisms, it is impossible to create new drugs for prophylaxis and treatment of age-related disturbances in motor function of the gastrointestinal (GI) motility.

Keywords: gastrointestinal motility, age.

\section{INTRODUCTION}

Despite more than 100 year-long history of studying the mechanisms of periodical motor activity of the gastrointestinal (GI) tract, its mechanisms have not been studied completely. They are studied intensively in our days as the disturbances of gastrointestinal motility underlaying in pathogeneses of many diseases, such as colitis, irritable bowel syndrome, gastroesophageal reflux disease, enterophaty, constipations. Today the most interesting and less studied is the question of age-related changes in motor function of the GI tract, since in old age dysmotility is most pronounced.

This review is devoted to analysis of available literature data on age-related functional and regulatory changes in the digestive tract. It is intended to evaluate the effectiveness of pharmacological correction of motility of the GI tract.

The aim of our study was to analyze agedependent changes in motor function of the GI tract. Data of PubMed MEDLINE National Library of Medicine in USA was used for a search.

Normal aging and motility. The analyzed research articles were devided into groups according to separate parts of the digestive tract. 
Oropharyngeal and esophageal motility. The scientific articles are indicating that the greatest risk of dysfunction associated with aging is shown in the upper digestive tract, including the oropharynx and esophagus. According to the literature dysphagia, esophageal diverticulum and gastroesophageal reflux (GER) are diseases which are characteristic to old people $[9,15,23,63]$. Dysphagia is associated with violations in functioning of the upper esophageal sphincter (UES) observed with age, namely, the neuro-muscular disorders [15].

In addition to these pathological states, changes in the GI tract of healthy people with occur in the process of aging were studied. It was shown that the amplitude and duration of the peristaltic waves of oropharyngeal elderly increased, but the amplitude of UES decreased $[18,22,27,29,63,66]$. These changes testify to the loss of basal tone of UES with age.

According to Herwaarden et al., in a group of women UES pressure was higher than in group of men, when the rest and relaxation periods were longer [29]. On the contrary, Shaker et al. did not find deterioration of the peristaltic waves parameters of the pharynx in the elderly individuals [63].

Ren et al. has studied stimulated motor activity of esophagus and showed that in the elderly compared with young, esophageal peristalsis induced or did not induce, or rarely evoked after stretching the esophagus. Rarely, there was a complete relaxation of lower esophageal sphincter (LES) in response to stretching of the esophagus with air [55]. After analysis of two other articles, it was found that the amplitude of peristaltic contractions was decreasing in the LES with age. These data are evidence that in elderly esophageal clearance after gastroesophageal reflux is longer than in the young people [19, 37].

Gastric motor function. With age, the number of $\mathrm{Gl}$ diseases increases, so it is almost impossible to conduct investigation in a group of healthy people older 70 years. Researchers have shown that the stomach emptying of liquids or mixed food is delayed in the elderly compared with young people $[7,16]$. Smiths et al. also showed the slower of emptying of liquids from the gastric with age in rats [65].

Similar data were shown by Shimamoto et al., who found that after meal peristalsis waves and strength of contractions in stomach were smaller in the elderly, and this reduction was greater in the inactive than in the active group of older people [64].

It is known that a pyloric part of the stomach plays an important role in food evacuation. It was found that in young people flow rate through the pyloric division is faster than in the elderly ones [45]. In contrast to these data, Fich et al. have shown that fast and food motility of the antral part of stomach do not change with age [20]. Madsen also found that evacuation of the stomach does not change with age $[39,40]$.

In other studies, it was found that in healthy elderly the perception of stretching of the stomach decreases without any periodical changes. Later the tone of the stomach after food consumption was reduced, compared to younger patients [53].

Small intestinal motility. At normal physiological conditions, fast motility of the small intestine is a cyclic process including periods of rest alternating and periods of work called the migrative motor complex (MMC). MMC consists of four phases whose duration may vary with age. The data of the various researchers are similar. It was shown that the duration of the phases of MMC, the speed of propagation and the maximum number of contractions during III phase of MMC of the small intestine did not differ in young and elderly $[20,21]$. In contrast, two other works showed that the duration of III phase MMC in the elderly was longer than in young people [32, 39].

ISSN 1996-4536 • Біологічні Студії / Studia Biologica • 2013 • Том 7/№2 • С. 185-194 
Articles devoted to the study of changes in food motility of the small intestine with age were published. It was established that the nature of the food motility stored in the elderly $[1,32,39]$. Sadik et al. showed that the transit of radio-opaque markers through the small intestine was faster in older women and women with overweight compared to normal individuals [59].

The large-scale study on 172 healthy adult humans was conducted by Saad et al. The aim was to record motility using the radio-sensitive capsule. A statistically significant decrease was found, since the passage of the capsule through the small intestine decreased on 12 min to every 10 years of age [58].

Motility of the colon. In our days, colon cancer occupies the 4th place in structure of malignant tumors in human. With age, a risk of cancer increases because the elderly are often observed constipation [54], which is one of the reasons for its occurrence. In the elderly, constipation is a result of the reduction in consumption of dietary fiber, reduced physical activity and disturbances of intestinal microflora. As a proof of this could be the work of Hopkins et al. who showed that age decreases the number of bifidobacteria in human large intestine [31].

16 articles dedicated to the issue of age-related changes of the colon motility were found in literature, but the presented data are contradictory. It was found that in the organism of elderly people, compared to young, a transit of the radiotracer particles is slowed in colon [39, 40]. An inverse correlation was established between the number of high-amplitude contractions of the colon and age in the fast period and after meal [13]. While other investigators did not receive statistically significant changes in colon motility with age [7, 43].

Eldery people often have the diverticulitis of colon. The main cause of diverticulitis appearance with age is weakened muscle wall of the colon [8]. This statement was confirmed experimentally, since it was shown that smooth muscle cells of the colon in rats (32 months) have limited ability to stretch and reduced contractile activity [6]. Also Robert et al. found that with age, decreases acetylcholine release by $50 \%$ in electrically stimulated preparations of rat colon [56]. It was suggested that reducing the length of the smooth muscle cells with age involves a reducing the distance between the contractile proteins during contraction which, in turn, is manifested in the reduced contractility and plasticity. Also, the reduction of current flow through calcium and potassium channels was shown in smooth muscle cells involved in the initiation of contractions of colon in old rats [69]. Besides, a significant effect of aging in rats manifested in delay of the passage of fecal masses and their formation in the colon [65].

Manometric studies indicate that a pressure is significantly reduced in the anal canal of women, but not in men, with age, but basal pressure decreases with age in both sexes [57]. Also, it was found that the threshold pressure for relaxation of anal sphincter and in case of defecation were lower in elderly than in younger study participants [3]. Taking into account these results, it was suggested that in elderly people fecal incontinence might appear [35], especially, if the cause of dysfunction is a degenerative change in the intrinsic sphincter [4], or disturbances in sphincter innervations [36, 46].

Age-related changes in regulatory mechanisms. In addition to anatomical and physiological aging changes in the structure and work of the GI tract, a cause of diseases of different parts of the digestive system might involve disturbances related to regulatory mechanisms. Since the activity of $\mathrm{Gl}$ tract is provided by intrinsic innervation such as enteric nervous system, the external regulation represents by sympathetic and 
parasympathetic systems, and visceral neurons, each of these parts of the regulation may be in danger of interruption in a varying degree.

The intrinsic innervation of the digestive tract represented myoenteric and submucosa plexuses. Since myoenteric plexus involved in the initiation and regulation of peristaltic waves, then any interruption of its structure and function affect motor activity of the digestive tract. The following seven articles demonstrated the decreases of the number of neurons in ganglia myoenteric plexus with age. Firstly, this fact was described by Santer and Baker [61] in rats, and other researchers have confirmed that this phenomenon is associated with aging in the intestine of many mammals, including guinea pigs [23], mice [14] and humane [12]. This statement about the death of cells in myoenteric plexus of small and large intestine has been demonstrated in rats with different conditions of existence [11, 30, 48, 49, 61].

Another interesting question is: when a reduction in the number of neurons in myoenteric plexus starts? After a series of studies in rats of different ages and analyzed the number of neurons in the small and large intestine, the authors found that loss of neurons begins in adulthood and progresses mostly during the remaining life of rodents $[48,51,67]$. Concerning changes of neurons with age in the stomach of rats, such statement is quite controversial. Some researchers did not find changes in different parts of stomach in rats [48], while others found a statistically significant decrease in number of neurons in the ganglion of antral part of stomach in 12 month mice, compared to 3-month ones [14]. Wade et al. obtained similar data on the intestine of different types of mammalians and showed that the number of neurons in submucosal and myoenteric plexuses decreased with age [70].

Submucosal plexus is the second of two major nerve plexus of intramural nervous system. Its neurons are located between the smooth muscle and mucous layers. This issue is described in three works demostrating that the number of neurons in the submucous plexus decreases with age in different parts of the digestive tract in rats [49] and mice [14, 42]. It was suggested that this reduction in number of neurons in the myoenteric plexus can cause a reduction in release of neurotransmitters and reduce the number of neurons that respond to signals.

It is known that gastrointestinal motor function is provided by normal distribution and functioning of the intestinal Cajal cells. It was found that violations of gastrointestinal motility were present in people with depletion of cells of Cajal [17]. Spanish scientists Gomez-Pinilla et al. analyzed possible age-related changes in Cajal cells in the tissues of stomach and colon in people of different ages. They found that with age, number and volume of these cells significantly reduced in both sexes [25].

External gastrointestinal innervation is provided by sympathetic, parasympathetic and visceral sensory innervation $[41,44,60]$. There is a point of view that age-related changes in motor function of the digestive tract may be associated with changes in different parts of the external innervation [5, 24, 61]. It was found that sympathetic innervation of myoenteric plexus deteriorates in rats with age [49]. Baker and Santer observed a decrease in fluorescence of noradrenergic axons and interruption in regulation of the myoenteric plexus in jejunum of rats aged from 12 to 18 months [2]. These researchers also noted the presence of swollen axons and bright, round structures in 24 month rats. They suggested that it is a sign of degeneration of axons. Similar data were obtained by Phillips at al., except that they have found these changes in the submucosal plexus of axons, whereas in the circular layer of smooth muscle of different parts of the digestive tract these axons were not found [51].

ISSN 1996-4536 • Біологічні Студії / Studia Biologica • 2013 • Том 7/№2 • С. 185-194 
The vagus provides both sensory (afferent fibers) and motor (efferent fibers) functions. Nerves of afferents vagus form a large network in smooth muscle, myoenteric plexus and, mucous. Phillips at al., tried to detect any changes in the nerve endings of the vagus nerve in different groups of rats [48]. They found that the density and distribution of the vagus endings in smooth muscle and myoenteric plexus of the stomach were stable in all groups of rats. In addition, the researchers found no age differences in the number of neurons myoenteric plexus, which is surrounded by the vagus. Later researchers used another marker that gives more detailed information about the morphology of the endings of vagus nerve. And found that with age in rats significant swelling occurs along the length of nerve endings in both smooth muscle and in myoenteric plexus of stomach. Moreover, in young rats, the sensory innervation of the villi by vagus consisted of free nerve endings, whereas in old rats, it was encased in small plates of degenerative nerve [52].

Initial afferent sensory fibers begin in the spinal ganglia and continue along the mesenteric arteries to the gastrointestinal tract and are located around the neurons in ganglia of the submucosal and myoenteric plexuses, and villus of mucosa. Spinal-brain afferents provide regulation of blood flow, nervous excitability, motor and secretory functions of the digestive tract $[10,47,68]$. Most spinal afferents that innervate $\mathrm{Gl}$ tract is positive to alpha-calcitonin related peptide (CGRP). External nature of CGRP-fibers in the digestive tract was confirmed by surgical cutting of external nerves GI tract or application neurotoxin capsaicin, and as a result, in both procedures a destruction of CGRPfibers in the digestive tract was observed [27, 37]. By using monoclonal antibodies to alpha-CGRP, it was found that neurons in the myoenteric plexus along the entire digestive tract and submucosal weaving in the colon were densely innervated by CGRPimmunoreactive nerves (CGRP-IR), forming a dense network around cells ganglia [51]. Innervation of myoenteric and submucosal plexuses by CGRP-IR-fibers was relatively stable in the different age groups of rats that were studied, but researchers have noticed a small amount of swollen dystrophic CGRP-IR-fibers in adult rats [51]. Data concerning age-related changes of visceral innervation are limited, and the reason for that might be the lack of technologies that can visualize these fibers.

Age-related intracellular changes. The muscle functions of different tissues change with age. Big number of works on the impact of aging on skeletal muscle or muscles cardiovascular system were published, but only few of them were performed on smooth muscle of the digestive tract. The researchers from the U.S.A. found that smooth-muscle cells of the colon in old rats possess limited ability to stretch and a decreased contractility. The average length of the muscle cells of old rats was shorter than in the young animals. It was suggested that the shortening of these cells with age involves shortening of distance between the sliding contractile proteins, which in turn affects a reduction in contractility of cells and a decreased plasticity [6].

Intracellular mechanism of contraction of smooth muscle consists of a cascade of protein phosphorylation. Ibitayo et al. found that during the contraction of muscle cells of rabbit colon the activity of Src-kinase dramatically increased [36]. Other researchers have shown that Src-kinase is not activated in old rats during contraction, compared to young animals [6]. Thus, with age, smooth muscle contraction was inhibited by tyrosine kinase.

Calcium $\left(\mathrm{Ca}^{2+}\right)$ is another necessary component of contraction. Intracellular calcium plays an important role in the mechanism of contraction-relaxation of the muscular 
cells. Ibitayo et al. showed that age decreases intracellular calcium levels in smooth muscle cells of colon. Such inhibition of Src-kinase was associated with a decrease in the intracellular calcium.

Another mechanism of muscle contraction is associated with the release of inositol 1,4,5-triphosphate and calcium. In this case calcium-calmodulin complex is important in the process of ageing. Since age decreases intracellular calcium levels, the calciumcalmodulin complex dissociates. As a result myosin light chain dephosphorylation and smooth muscle relaxation.

It is known that protein kinase $\mathrm{C}$ (PKC) is activated in cells of different tissue systems, such as smooth muscle cells of colon, cells of blood vessels, and heart of the neonatal rats [34]. It was shown that in old rats, $\gamma$-isoform of PKC is activated, whereas in young rats $\alpha, \beta, \gamma$ isoforms are activated [33].

Xiong et al. found that in the smooth muscle cells of colon in old rats, $\mathrm{K}^{+}$and $\mathrm{Ca}^{2+}$ currents are reduced through appropriate channels that affect on the beginning of the contraction [69].

\section{CONCLUSION}

The mechanisms of age-related disorders in motor function of the digestive tract have not been established, despite large number of studies devoted to this problem. Today, many people suffer from the emergence of constipation, especially with age increased incidence of this disease. Many modern laxatives have negative features, such as addictive. The reveal of age-related mechanisms in the motor function could facilitate creation of new drugs which would not have addictive effects.

1. Abalo R., Vera G., Rivera A.J. et al. Age-related changes in the gastrointestinal tract: a functional and immunohistochemical study in guinea-pig ileum. Life Sci, 2007; 80(26): 2436-45.

2. Baker D.M., Santer R.M. A quantitative study of the effects of age on the noradrenergic innervation of Auerbach's plexus in the rat. Mech. Ageing. Dev, 1988a; 42: 147-158.

3. Bannister J.J. Abouzekry L., Read N.W. Effect of aging on anorectal function. Gut,1987; 28: 353-357.

4. Barrett J.A., Brocklehurst J.C., Kiff E.S. Anal function in geriatric patients with faecal incontinence. Gut, 1989; 30(9): 1244-1251.

5. Bergman E., Ulfhake B. Loss of primary sensory neurons in the very old rat: neuron number estimates using the disector method and confocal optical sectionin. J. Comp. Neurol, 1998; 396: 211-222.

6. Bitar K., Greenwood-Van Meerveld B. Aging and gastrointestinal neuromuscular function: insights from within and outside the gut. Neurogastroenterol. Motil, 2011; 23(6): 490-501.

7. Brogna A. Ferrara R., Bucceri A.M. Influence of aging on gastrointestinal transit time. An ultrasonographic and radiologic study. Invest. Radiol, 1999; 34: 357-359.

8. Bhutto A., Morley J.E. The clinical significance of gastrointestinal changes with aging. Curr. Opin. Clin. Nutr. Metab. Care, 2008; 11(5): 651-660.

9. Castell D.O. Esophageal disorders in the elderly. Gastroenterol. Clin. North. Am, 1990; 19(2): 235-238.

10. Chiocchetti R., Grandis A., Bombardi C. Extrinsic and intrinsic sources of calcitonin generelated peptide immunoreactivity in the lamb ileum: a morphometric and neurochemical investigation. Cell Tissue Res, 2006; 323: 183-196.

11. Cowen T., Johnson R.J., Soubeyre V. Restricted diet rescues rat enteric motor neurones from age related cell death. Gut, 2000; 47(5): 653-660.

ISSN 1996-4536 • Біологічні Студії / Studia Biologica • 2013 • Том 7/№2 • С. 185-194 
12. De Souza R.R., Moratelli H.B., Borges N. Age-induced nerve cell loss in the myenteric plexus of the small intestine in man. Gerontology, 1993; 39(4): 183-188.

13. Di Lorenzo C., Flores A.F., Hyman P.E. Age-related changes in colon motility. J. Pediatr, 1995; 127(4): 593-596.

14. El-Salhy M., Sandström O., Holmlund F. Age-induced changes in the enteric nervous system in the mouse. Mech. Ageing. Dev, 1999; 107(1): 93-103.

15. Ergun G.A., Miskovitz P.F. Aging and the esophagus: common pathologic conditions and their effect upon swallowing in the geriatric population. Dysphagia, 1992; 7: 58-63.

16. Evans M.A., Triggs E.J., Cheung M.J. Gastric emptying rate in the elderly: implications for drug therapy. Am. Geriatr. Soc, 1981; 29(5): 201-205.

17. Farrugia G. Interstitial cells of Cajal in health and disease. Neurogastroenterol. Motil, 2008; 20: 54-63.

18. Ferriolli E., Dantas R.O., Oliveira R.B., Braga F.J. The influence of ageing on oesophageal motility after ingestion of liquids with different viscosities. Eur. J. Gastroenterol. Hepatol, 1996; 8(8): 793-798.

19. Ferriolli E., Oliveira R.B., Matsuda N.M. Aging, esophageal motility, and gastroesophageal reflux. Am. Geriatr. Soc, 1998; 46(12): 1534-1537.

20. Fich A., Camilleri M., Phillips S.F. Effect of age on human gastric and small bowel motility. J. Clin. Gastroenterol, 1989; 11(4): 416-420.

21. Firth M., Prather C.M. Gastrointestinal motility problems in the elderly patient. Gastroenterology, 2002; 122: 1688-1700.

22. Fulp S.R., Dalton C.B., Castell J.A. Aging-related alterations in human upper esophageal sphincter function. Am. J. Gastroenterol, 1990; 85: 1569-1572.

23. Furuta K., Kushiyama Y., Kawashima K., Shibagaki K. Comparisons of symptoms reported by elderly and non-elderly patients with GERD. J. Gastroenterol, 2012; 47(2):144-149.

24. Gabella $G$. Fall in the number of myenteric neurons in aging guinea pigs. Gastroenterology, 1989;. 96(6): 1487-1493.

25. Gai W.P., Blumbergs P.C., Geffen L.B. Age-related loss of dorsal vagal neurons in Parkinson's disease. Neurology, 1992; 42(11): 2106-2111.

26. Gomez-Pinilla Pedro J. Changes in Interstitial Cells of Cajal with Age in the Human Stomach and Colon. Neurogastroenterol. Motil, 2011; 23: 36-44.

27. Grande L., Lacima G., Ros E. Deterioration of esophageal motility with age: a manometric study of 79 healthy subjects. Am. J. Gastroenterol, 1999; 94: 1795-1801.

28. Green T., Dockray G.J. Calcitonin gene-related peptide and substance P in afferents to the upper gastrointestinal tract in the rat. Neurosci. Lett, 1987; 76: 151-156.

29. Herwaarden M.A., Katz P.O., Gideon R.M., Barrett J. Are manometric parameters of the upper esophageal sphincter and pharynx affected by age and gender? Dysphagia, 2003; 18(3): 211-217.

30. Hoyle C.H., Saffrey M.J. Effects of aging on cholinergic neuromuscular transmission in isolated small intestine of ad libitum fed and calorically-restricted rats. Neurogastroenterol. Motil, 2012; 24(6): 586-92.

31. Hopkins M.J., Sharp R., Macfarlane G.T. Variation in human intestinal microbiota with age. Dig. Liver Dis, 2002; 34: S12-18.

32. Husebye E., Engedal $K$. The patterns of motility are maintained in the human small intestine throughout the process of aging. Scand. J. Gastroenterol,1992; 27(5): 397-404.

33. Ibitayo A.I., Tsunoda Y., Nozu F. Src kinase and PI 3-kinase as a transduction pathway in ceramide-induced contraction of colonic smooth muscle. Am. J. Physiol, 1998; 275: G705-G711.

34. Ibitayo A.I., Sladick J., Tuteja S. HSP27 in signal transduction and association with contractile proteins in smooth muscle cells. Am. J. Physiol, 1999; 277: G445-G454.

35. Kang H.W., Jung H.K., Kwon K.J. Prevalence and predictive factors of fecal incontinence. J. Neurogastroenterol. Motil, 2012; 18(1): 86-93. 
36. Laurberg S., Swash M. Effects of aging on the anorectal sphincters and their innervations. Dis. Colon. Rectum, 1989; 32(9): 737-742.

37. Lee Y., Shiotani Y., Hayashi N. Distribution and origin of calcitonin gene-related peptide in the rat stomach and duodenum: an immunocytochemical analysis. J. Neural. Transm, 1987; 68: $1-14$.

38. Lee J., Anggiansah A., Anggiansah R., Young A. Effects of age on the gastroesophageal junction, esophageal motility, and reflux disease. Clin. Gastroenterol. Hepatol, 2007; 5(12): 1392-1398.

39. Madsen J.L. Evffects of gender, age, and body mass index on gastrointestinal transit times. Dig. Dis. Sci, 1992; 37(10):1548-1553.

40. Madsen J.L., Graff J. Effects of ageing on gastrointestinal motor function. Age Ageing, 2004; 33(2): 154-159.

41. Marín J. Age-related changes in vascular responses: a review. Mech. Ageing. Dev, 1995; 79: 71-114.

42. Meciano Filho J., Carvalho V.C., de Souza R.R. Nerve cell loss in the myenteric plexus of the human esophagus in relation to age: a preliminary investigation. Gerontology, 1995; 41(1): $18-21$.

43. Meir R., Beglinger C., Dederding J.P. Age- and sex-specific standard values of colonic transit time in healthy subjects. Schweiz. Med. Wochenschr, 1992; 122(24): 940-943.

44. Morley J.E. The aging gut: physiology. Clin. Geriatr. Med, 2007; 23(4): 757-767.

45. O'Donnovan D., Hausken T., Lei Y. Effect of aging on transpyloric flow, gastric emptying, and intragastric distribution in health humans: impact on glycemia. Dig. Dis. Sci, 2005; 50: 671-676.

46. O'Mahony D., O'Leary P., Quigley E.M. Aging and intestinal motility: a review of factors that affect intestinal motility in the aged. Drugs Aging, 2002; 19: 515-527.

47. Orr W.C., Chen C.L. Aging and neural control of the GI tract: IV. Clinical and physiological aspects of gastrointestinal motility and aging. Am. J. Physiol. Gastrointest. Liver. Physiol, 2002; 283: G1226-G1231.

48. Phillips R.J., Powley T.L. As the gut ages: timetables for aging of innervation vary by organ in the Fischer 344 rat. J. Comp. Neurol, 2001; 434(3): 358-377.

49. Phillips R.J., Rhodes B.S., Powley T.L. Effects of age on sympathetic innervation of the myenteric plexus and gastrointestinal smooth muscle of Fischer 344 rats. Anat. Embryol. (Berl), 2006; 211(6): 673-683.

50. Phillips R.J., Rhodes B.S., Powley T.L. Age-related neuronal loss in the submucosal plexus of the colon of the Fischer 344 rats. Neurobiol Aging, 2006a; 43: 17-29.

51. Phillips R.J., Powley T. Innervation of the gastrointestinal tract: patterns of aging. Auton. Neurosc, 2007; 136: 1-19.

52. Powley T.L., Phillips R.J. Advances in neural tracing of vagal afferent nerves and terminals. Methods and New Frontiers in Neuroscience, 2005; 28: 123-145.

53. Rayner C.K., MacIntosh C.G., Chapman I.M. Effects of age on proximal gastric motor and sensory function. Scand. J. Gastroenterol, 2000; 35(10): 1041-1047.

54. Rayner C.K., Horowitz M. Physiology of the ageing gut. Curr. Opin. Clin. Nutr. Metab. Care, 2013; 16(1): 33-38.

55. Ren J., Shaker R., Kusano M., Podvrsan B. Effect of aging on the secondary esophageal peristalsis: presbyesophagus revisited. Am. J. Physiol, 1995; 268: G772-779.

56. Roberts D., Gelperin D., Wiley J.W. Evidence for age-associated reduction in acetylcholine release and smooth muscle response in the rat colon. Am. J. Physiol, 1994; 267: G515-22.

57. Ryhammer A.M. Laurberg S., Sørensen F.H. Effects of age on anal function in normal women. Int. J. Colorectal. Dis, 1997; 12: 225-229.

58. Saad R.J., Semler J.R., Wilding G.E. The effects of age on regional and whole gut transit times in healthy adults. Gastroenterol, 2010; 138: S-127.

ISSN 1996-4536 • Біологічні Студії / Studia Biologica • 2013 • Том 7/№2 • С. 185-194 
59. Sadik R., Abrahamsson H., Stotzer P.O. Gender differences in gut transit shown with a newly developed radiological procedure. Scand. J. Gastroenterol, 2003; 38(1): 36-42.

60. Salles N. Basic mechanisms of the aging gastrointestinal tract. Dig. Dis, 2007; 25(2): 112-117.

61. Santer R.M., Baker D.M. Enteric neuron numbers and sizes in Auerbach's plexus in the small and large intestine of adult and aged rats. J. Auton. Nerv. Syst, 1988; 25(1): 59-67.

62. Santer R.M., Dering M.A., Ranson R.N. Differential susceptibility to ageing of rat preganglionic neurones projecting to the major pelvic ganglion and of their afferent inputs. Auton. Neurosci, 2002; 96: 73-81.

63. Shaker R., Ren J., Podvrsan B., Dodds W.J. Effect of aging and bolus variables on pharyngeal and upper esophageal sphincter motor function. Am. J. Physiol, 1993; 264: G427-32.

64. Shimamoto C., Hirata I., Hiraike Y., Takeuchi N. Evaluation of gastric motor activity in the elderly by electrogastrography and the (13)C-acetate breath test. Gerontology, 2002; 48(6): 381-386.

65. Smits G.J. Influence of age on cholinergic and inhibitory nonadrenergic noncholinergic responses in the rat ileum. Eur. J. Pharmacol, 1996; 303: 79-86.

66. Tack J., Vantrappen G. The aging oesophagus. Gut, 1997; 41(4): 422-424.

67. Thrasvoulou C., Soubeyre V., Ridha H. Reactive oxygen species, dietary restriction and neurotrophic factors in age-related loss of myenteric neurons. Aging. Cell, 2006; 5(3): 247-57.

68. Vanner S. Corelease of neuropeptides from capsaicin-sensitive afferents dilates submucosal arterioles in guinea pig ileum. Am. J. Physiol, 1994; 267: G650-655.

69. Xiong Z., Sperelakis N., Noffsinger A., Fenoglio-Preiser C. Potassium currents in rat colonic smooth muscle cells and changes during development and aging. Pflugers. Arch, 1995; 430: 563-72.

70. Wade1 P. R., Cowen T. Neurodegeneration: a key factor in the ageing gut. Neurogastroenterology. Motil, 2004; 16: 19-23.

\title{
ВІКОВІ ЗМІНИ МОТОРИКИ ТРАВНОГО ТРАКТУ
}

\author{
О. Ю. Єфіменко, Ю. О. Савченко, Т. В. Берегова \\ Київський національний університет імені Тараса Шевченка \\ вул. Володимирська, 64/13, Київ 01601, Україна
}

Механізми моторної функції травного тракту досліджуються понад 100 років. Незважаючи на це, вони до кінця не встановлені. Вивчення даного питання $€$ надзвичайно важливим, оскільки порушення моторики лежать в основі патогенезу ряду захворювань, таких як коліти, закрепи, синдром подразненого кишечника та ін. Представлений огляд літератури присвячений аналізові літературних джерел щодо вікових змін моторної функції травного тракту. Матеріал даної статті систематизовано по кожному відділу травного тракту. Ми проаналізували результати досліджень науковців, присвячених функціональним і регуляторним змінам травного тракту з віком. У результаті нами було зроблено висновок, що механізми, які лежать в основі патогенезу вікових захворювань травного тракту, до кінця не з'ясовані. Без встановлення цих механізмів неможливо створити нові лікарські засоби для профілактики і лікування вікових порушень моторної фрункції шлунковокишкового тракту.

Ключові слова: моторика шлунково-кишкового тракту, вік. 


\title{
ВОЗРАСТНЫЕ ИЗМЕНЕНИЯ МОТОРИКИ ПИЩЕВАРИТЕЛЬНОГО ТРАКТА
}

\author{
Е. Ю. Ефименко, Ю. А. Савченко, Т. В. Берегова \\ Киевский национальный университет имени Тараса Шевченко \\ ул. Владимирская, 64/13, Киев 01601, Украина
}

Механизмы моторной функции пищеварительной системы исследуются более 100 лет. Несмотря на это, они до конца не установлены. Изучение данного вопроса является очень важным, так как нарушение моторики лежит в основе патогенеза многих заболеваний таких, как колиты, запоры, синдром раздраженного кишечника и др. Представленный обзор литературы посвящен анализу литературных источников о возрастных изменениях моторной функции пищеварительного тракта. Материал данной статьи систематизирован по каждому отделу пищеварительного тракта. Проанализированы результаты исследований, посвященных фрункциональным и регуляторным изменениям пищеварительного тракта с возрастом. В результате проведенного анализа сделан вывод, что механизмы, которые лежат в основе патогенеза возрастных заболеваний пищеварительного тракта, до конца не выяснены. Без установления таких механизмов невозможно создать новые лекарственные средства для профилактики и лечения возрастных нарушений моторной функции желудочно-кишечного тракта.

Ключевые слова: моторика желудочно-кишечного тракта, возраст.

Одержано: 08.02.2013 